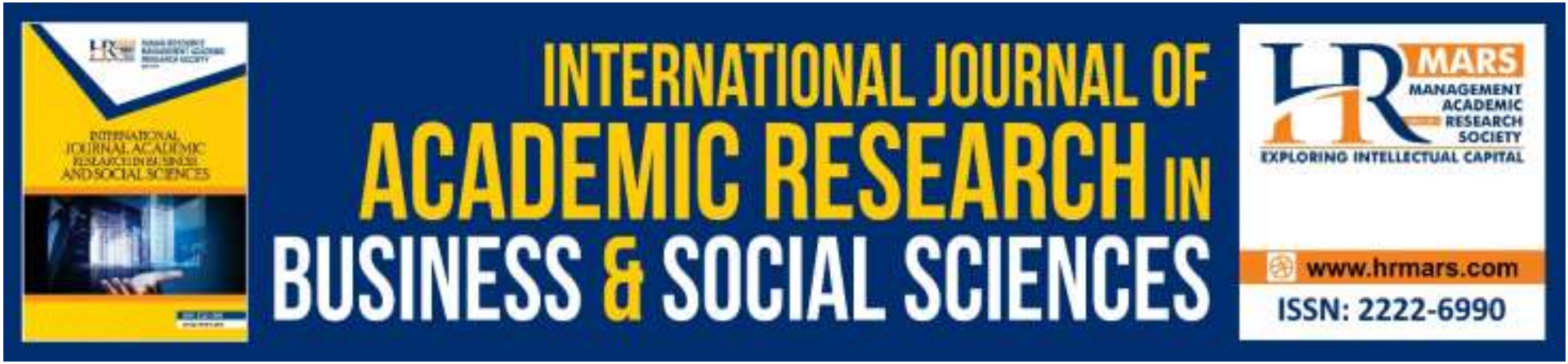

\title{
Challenges in Implementing Muslim Friendly Hospitality Services (MFHS) in Shariah-Compliant Hotels in Malaysia
}

Nur Athirah Abd Razak, Raja Nerina Raja Yusof, Yuhanis Ab Aziz

To Link this Article: http://dx.doi.org/10.6007/IJARBSS/v9-i10/6459

DOI: 10.6007/IJARBSS/v9-i10/6459

Received: 19 September 2019, Revised: 29 September 2019, Accepted: 07 October 2019

Published Online: 29 Oct 2019

In-Text Citation: (Razak, Yusof, \& Aziz, 2019)

To Cite this Article: Razak, N. A. A., Yusof, R. N. R., \& Aziz, Y. A. (2019). Challenges in Implementing Muslim Friendly Hospitality Services (MFHS) in Shariah-Compliant Hotels in Malaysia. International Journal of Academic Research in Business and Social Sciences, 9(10), 67-72.

Copyright: (C) 2019 The Author(s)

Published by Human Resource Management Academic Research Society (www.hrmars.com)

This article is published under the Creative Commons Attribution (CC BY 4.0) license. Anyone may reproduce, distribute, translate and create derivative works of this article (for both commercial and non-commercial purposes), subject to full attribution to the original publication and authors. The full terms of this license may be seen at: http://creativecommons.org/licences/by/4.0/legalcode

Vol. 9, No. 10, 2019, Pg. 96 - 104

http://hrmars.com/index.php/pages/detail/IJARBSS

JOURNAL HOMEPAGE

Full Terms \& Conditions of access and use can be found at http://hrmars.com/index.php/pages/detail/publication-ethics 


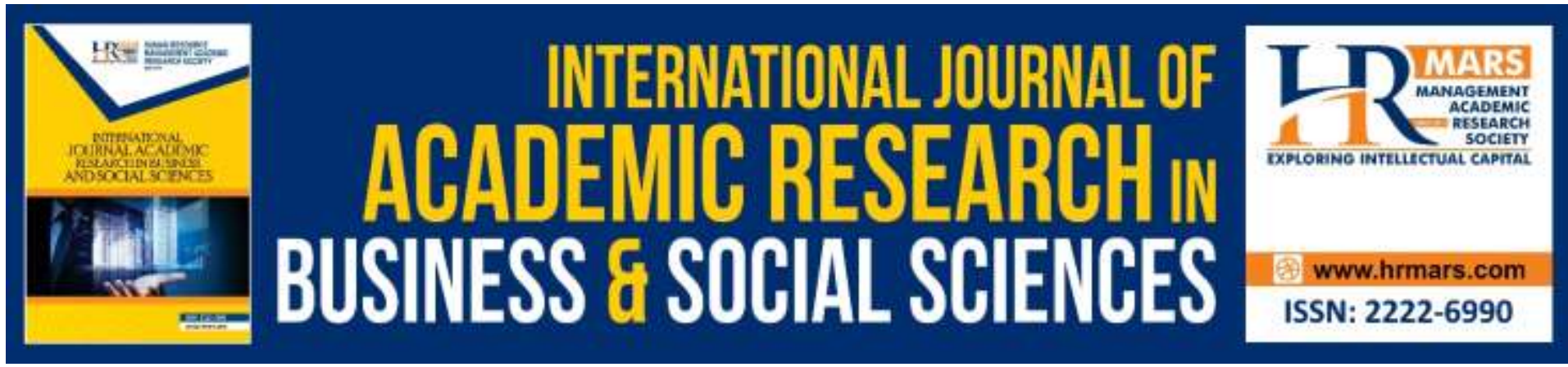

\title{
Challenges in Implementing Muslim Friendly Hospitality Services (MFHS) in Shariah-Compliant Hotels in Malaysia
}

\author{
Nur Athirah Abd Razak, Raja Nerina Raja Yusof \\ Halal Products Research Institute, Universiti Putra Malaysia \\ Email: nerina@upm.edu.my \\ Yuhanis Ab Aziz \\ Faculty of Economics and Management, Universiti Putra Malaysia
}

\begin{abstract}
Due to different understanding of halal accommodation according to the madhabs (Islamic schools of thought) and practice levels in Islam, Shariah-compliant hotels (SCHs) globally faced challenges related to the implementation of Muslim-friendly hospitality services (MFHS) in their accommodation establishments. Hence, this study seeks to identify the challenges of Shariah-compliant hotels in Malaysia in implementing MFHS. The study uses qualitative approach where data collection was done through observations and in-depth semi-structured interviews with managers from three Shariah-compliant hotels. Overall, findings showed that the hotels face challenges and issues arising from customers' demands and their existing facilities and services. This study has identified a list of main challenges faced by Shariahcompliant hoteliers which can be a point of reference for current and future hotel managers. It is recommended that hotel operators learn from the challenges faced by them and improve their services for Muslim guests.
\end{abstract}

Keywords: Muslim Friendly, Shariah-Compliant Hotel, Hospitality, Challenges, Malaysia

Introduction

Malaysia's Islamic Tourism Centre (ITC) reported that Malaysia is the most preferred destination for Muslim travellers worldwide, hosting 5.1 million Muslim travellers in 2015 (Karim, Ahmad \& Zainol, 2017). Tourism industry has contributed to the growth of Malaysia's economy especially in the hospitality sector, particularly in Muslim-friendly tourism (CrescentRating, 2017). Accommodation is one of the important aspects of a Muslim-friendly experience for tourists, and in Malaysia, among the hotels that are listed as Shariah-compliant by ITC are PNB Darby Park Executive Suites Hotel in Kuala Lumpur, Grand Pacific Hotel and De Palma Hotel in Ampang (Mohd, 2011).

A study by the Islamic Tourism Center (ITC) showed that the readiness of the Malaysian tourism industry towards Shariah compliance have a positive impact on the tourism sector. 
Hence, hotels can be a place for tourists to fulfil their obligation to Islam, such as the five daily prayers and ease of searching for halal foods (Satar, 2016). In order to guide hotels to be Shariah-compliant, the Department of Standards Malaysia, in collaboration with ITC, launched a standard which provides guidelines for industry players to adapt to their Muslim customers. The standard is named Muslim Friendly Hospitality Services (MFHS)-Requirements (MS 2610:2015) which serves to maintain and protect the integrity of the systems and services of tourism products of Islamic countries (Mustaffa, 2016).

Nevertheless, COMCEC (2017) found that Shariah-compliant hotels (SCHs) globally faced challenges related to the implementation of Muslim friendly hospitality services (MFHS) in their accommodation establishments. This is due to different understanding of 'halal' accommodation according to the madhab and practice levels. Moreover, Muslim guests and non-Muslim guests have different requirements and assessing halal elements is difficult due to the ever-changing products. In the Malaysian setting, studies on the challenges of SCHs are scarce and needs updating especially after the introduction of Muslim Friendly Hospitality Services (MFHS)-Requirements (MS 2610:2015).

Although review of the literature revealed some challenges in operating Malaysian Shariahcompliant hotels, the studies were conducted more than five years ago (Samori \& Rahman, 2013; Albattat \& Mat Som, 2013), and current data and information are needed to update on this information. In addition, there is still not many exploratory research conducted in the Malaysian hotel industry looking from a comprehensive view of a hotel's operations.

Hence, the objective of this paper is to identify the challenges of Shariah-compliant hotels in Malaysia in implementing Muslim friendly hospitality services (MFHS). The findings will produce a list of challenges faced by SCHs in implementing MFHS according to the Malaysian standards that may affect the customers and hotels. This contributes as knowledge to prospective hoteliers who want to adopt Muslim-friendly standards as well as to authority bodies and government agencies which monitor services rendered by hotels in Malaysia.

\section{Literature Review}

\section{Shariah-Compliant Hotels}

A Shariah-compliant hotel is a hotel that meets the needs of Muslim tourists based on the Shariah law where the hotel normally uses certain standards or laws to certify the requirements provided to achieve Shariah compliance. In short, Shariah-compliant hotels adhere to the Shariah requirements according to Islamic teachings in the hotel management and operations (Jais, 2017).

and Rosenberg and Choufany (2009) as shown in Figure 1 and Table 1, respectively. Rosenberg and Choufany (2009) divided their attributes into three which are operations, design and interior and finance, while Henderson's (2010) list is more general. However, both perspectives highlighted similar characteristics such as halal food, separate facilities for different genders, moderate types of entertainments, predominantly Muslim employees, conservative dress codes and Islamic hotel room design and interior details. 


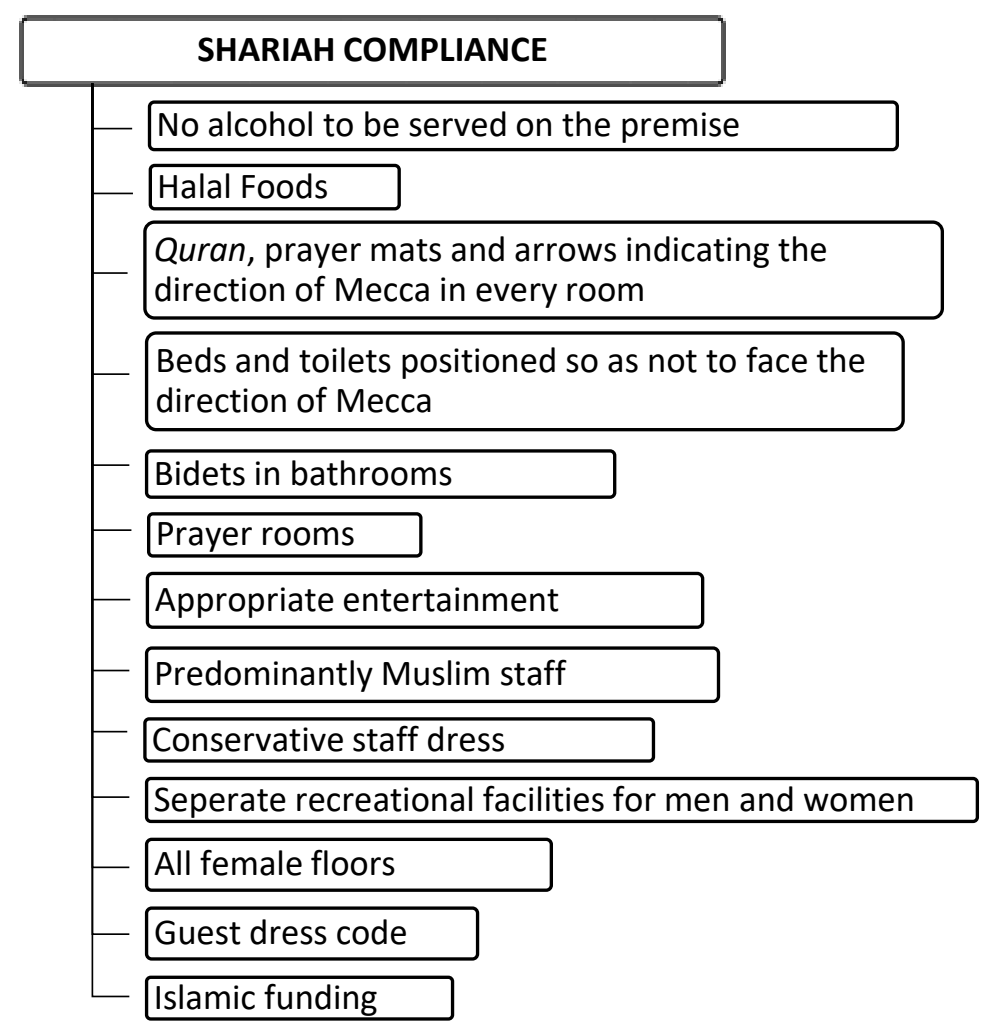

Figure 1: The attributes of SCH by Henderson (2010)

(Source: Henderson, 2010)

Table 1: $\quad$ The attributes of SCH by Rosenberg and Choufany (2009)

\begin{tabular}{|c|c|c|}
\hline OPERATIONS & DESIGN AND INTERIORS & FINANCIAL \\
\hline Halal food only & $\begin{array}{l}\text { Larger function rooms for males } \\
\text { and females separately }\end{array}$ & \multirow{3}{*}{$\begin{array}{l}\text { Hotel financial is } \\
\text { Islamic financial }\end{array}$} \\
\hline No alcohol & $\begin{array}{l}\text { Markers in each rooms indicating of } \\
\text { kiblat }\end{array}$ & \\
\hline Majority of staff of Muslim faith & No entertainment venues & \\
\hline \multirow{2}{*}{$\begin{array}{l}\text { Female staff for single female } \\
\text { floors, male staff for single male } \\
\text { floor }\end{array}$} & $\begin{array}{l}\text { Beds and toilets should not face } \\
\text { kiblat }\end{array}$ & \multirow{4}{*}{$\begin{array}{l}\text { The hotel should follow } \\
\text { the zakat principles }\end{array}$} \\
\hline & $\begin{array}{l}\text { Art in the hotel does not depict the } \\
\text { human form }\end{array}$ & \\
\hline Conservative television service & $\begin{array}{l}\text { Separate wellness facilities for } \\
\text { males and females }\end{array}$ & \\
\hline $\begin{array}{l}\text { Quran and sajada available in } \\
\text { each room }\end{array}$ & $\begin{array}{l}\text { Separate floor for males, females } \\
\text { and families }\end{array}$ & \\
\hline
\end{tabular}

(Source: Rosenberg and Choufany, 2009) 


\section{Muslim Friendly Hospitality Services- Requirements (MS2610: 2015)}

In 2015, the Department of Standards Malaysia established a standard called Muslim Friendly Hospitality Services-Requirements (MS 2610:2015). According to Shariah guidelines, this standard aims to ensure that products and services provided to Muslim travellers are in accordance to the Shariah principles and to increase customer satisfaction by fulfilling the customer requirements (Department of Standards Malaysia, 2015). However, this standard is optional and its use is voluntary (Samori \& Sabtu, 2014).

The organization should ensure that accommodation premises are in compliance with the Muslim Friendly Hospitality Services (MFHS) requirements. For example, a pet of non-halal delineation is prohibited in the accommodation area. Furthermore, the rooms should have available floor space for Muslim guests to perform solah (daily prayers) and the washroom should be completed with bidet, hand shower or water hose and kept clean. The organization should also mark the qibla (Mecca) direction, which is verified by a qualified authority. In addition, the rooms must have personal care facilities or products suitable for Muslim use and no alcoholic beverages and intoxicants are stored in the room's refrigerator (Department of Standards Malaysia, 2015). For food and beverages, the organization's kitchen must be certified halal by the relevant authority and during Ramadan, information on the time and meals for sahur (pre-dawn meal) and iftar (breaking fast) should be made available. Moreover, accommodation premises should also allocate public musalla (prayer rooms) for Muslims and the public musalla must be located at a suitable place and has a signboard dedicated especially for musalla and it should be well lit with enough ventilation to keep it clean and well maintained (Department of Standards Malaysia, 2015).

\section{Challenges to Muslim-Friendly Hotels}

Globally, hoteliers face some challenges in developing and operating halal hotels. According to Rosenberg and Choufany (2009), the challenge of implementing SCH is the loss of income from the sales of alcoholic beverages which affect the food and beverage profits. Furthermore, the prohibition of alcohol has an influence on the decreased number of customers who come only to eat and dine at the hotel premise. In the European cities, Almulla Hospitality was the first to introduce the Shariah-compliant hotel concept. Reportedly, this concept of SCH was a challenge for their four and five-star hotels because of the expectations of European hotel guests of exclusive bars in the hotels for them to relax in.

Samori and Rahman (2013) found out from their study that among the challenges for SCHs are the separation of rooms and floors for men, women, and families because it complicates planning and capacity as well as affects the design and interior. On top of that, hoteliers need to maximize staff of both sexes and to ensure productivity and quality of service. The hoteliers are in a dilemma because they have to satisfy Muslim and non-Muslim guests so that they can avoid any conflicts arising between them.

Moreover, many accommodation operators claim the risk of alienating non-Muslim guests will lead them to lose their income and reservations if they participate in this Islamic friendly standard. The separation of swimming pools or gymnasiums for men and women is a big challenge for operational hotels because of the cost to incorporate such a policy. Some accommodation providers address this challenge by offering different opening hours for men and women for the use of swimming pools and gymnasium facilities, though this was met by 
complaints by some travellers because families traveling together, including Muslim guests, may want to enjoy the facilities together (COMCEC Coordination Office, 2017).

Meanwhile, Karim et al. (2017) also stated that changing the position of beds and toilets away from the direction of Mecca will take too much time and can be very costly. Besides that, the inability to make room profit is also an issue when hotel management needs to allocate male and female housekeepers to the segregated female and male floors to make the guest rooms. In addition, there are also the issues of the appointment of an Imam (Muslim spiritual leader) to lead Friday prayers that will affect the human resource cost and the approval to have a Friday prayer in a hotel when there is a mosque nearby.

In summary, implementing Muslim-Friendly Hospitality Services in Shariah-compliant hotels $(\mathrm{SCH})$ come with various aspects of challenges. This is more so for conventional hotels which aspires to change into SCHs. It requires a great level of commitment from the hotels and requires expensive renovation efforts.

\section{Methodology}

The study uses qualitative inquiry through multiple case studies approach. Three Malaysian Shariah-compliant hotels, which are De Palma Hotel in Ampang, Adya Hotel in Langkawi and Grand Bluewave Hotel in Shah Alam, gave their consent to be participants for the study. Indepth semi-structured interviews and observations were conducted from April to September 2018 with managers in different departments of the hotels and the participants are codenamed as below:

Table 2: Code names of respondents of interviews

\begin{tabular}{|c|l|l|}
\hline CODE NAMES & \multicolumn{1}{|c|}{ IN CHARGE OF } & \multicolumn{1}{c|}{ ORGANIZATION } \\
\hline D1 & Operations & De Palma Hotel Ampang \\
\hline A1 & Customer Relationship & Adya Hotel Langkawi \\
\hline G1 & Human Resources & $\begin{array}{l}\text { Grand Bluewave Hotel Shah } \\
\text { Alam }\end{array}$ \\
\hline
\end{tabular}

\section{Findings}

Based on the interviews conducted, there were several challenges that occurred in the three hotels during the implementation of Muslim friendly hospitality services in the hotels. Among the highlighted issues were 1) changing room facilities in the hotels, 2) customer's perception, 3 ) customer and supplier compliance, and 4) satisfying diverse customers.

The first issue is about changing facilities in the hotels. According to D1, De Palma Hotel Ampang was established in 1996 and the hotel was not originally build for Shariahcompliance. Hence, among the challenges for the hotel was to change the room facilities according to shariah standards. For example, the hotel rooms' bed and toilet position were not shariah-compliant since they were facing the kiblat (the direction of Mecca). However, the bed could not be moved but the toilets were changed to avoid facing the kiblat.

As for Adya Hotel Langkawi, there were several issues determined as challenges for its hotel operations. The first issue was regarding customer's perception. According to A1, on the one hand, there were hotel guests who cannot accept that the hotel was Shariah-compliant, until they checked out of the hotel. On the other hand, because the use of gymnasium facilities lack demand from hotel guests, Adya Hotel decided to open up for both men and women at 
the same operating hours, and due to this, they were criticized as being not Shariahcompliant. According to D2, there were a gymnasium and a spa when the hotel was a conventional hotel. However, once the hotel became a Shariah-compliant hotel (SCH), the gymnasium and spa had to be shut down.

"The time we were conventional ... the hotel used to have the gym. And then there are a lot of complaints... When we consider this thing back we close the spa to get rid of doubts ... we have a proposal in the meeting at the exco level that she wants to make it a spa for ladies only." (D2, 2018)

The second issue was on customer and supplier compliance. There were cases where customers of the hotel wanted to have a wedding party and bring wine into the event. The hotel directly denied the event from being held at the hotel even though the guests were willing to pay an expensive price for it. In addition, there were times when suppliers delivered new products (i.e. food materials) that were different from the regular orders because of some reasons, thus the hotel had to refuse them as the hotel was unsure of its halal status. Similarly, as mentioned by G1, there are several challenges faced by Grand Bluewave Hotel Shah Alam in its hotel operation. There are food stuffs that did not have halal certification but were needed in preparing certain foods, such as western and Japanese foods. Thus, the chef had to search for other suitable halal ingredients to make the food tastes similar to the original menu. However, getting the original taste was difficult.

Furthermore, there were also issues about satisfying diverse customers' needs. For example, there were complaints from Grand Bluewave Hotel Shah Alam's guests about the adzan and Quran recitation as being too loud and disturbed the hotel guests even though it came from the mosque adjacent to the hotel.

"On Adzan and Quran recitation ... Some of the guests understand but some do not understand. They remembered that it was annoying. Even though here when it was recited from the mosque we got a comment from the guest. Comments from online... So, our international guest room will not face the mosque but will be facing the front." $(G 1,2018)$

To resolve the issue, the hotel had moved all international hotel guests into rooms that did not overlook the mosque. Another challenge was similar to De Palma Hotel Ampang, that the layout of the beds and toilets in the hotel rooms cannot be changed due to wiring factors.

\section{Discussion}

In this study, there were indeed challenges faced by the three hotels in their SCH operations. Overall, it can be seen that the hotels face challenges and issues arising from customers' demands and their existing facilities and services.

Challenges were mainly from the facilities and structure of the hotel, which was the case for De Palma Hotel Ampang due to the long standing factor of the hotel building where the layout of the furniture in the hotel room cannot be changed according to Muslim-friendly themes. Renovating the hotel would be expensive. Besides that, customer satisfaction is also a main issue in the three hotels' operations because in several cases, the hotel cannot fulfil all customers' demands. This was evident in Adya Hotel Langkawi where they faced dissatisfaction by Muslim clients when offering its gymnasium to both genders at the same time, when in fact the demand for the facility was very low to rationalize such a policy. 
Meanwhile, Grand Bluewave Hotel Shah Alam faced challenges in obtaining halal ingredients for the preparation of halal food at its hotel. Since the hotel provided a wide range of international cuisines, preparing the cuisines according to the original recipe was a challenge using only halal ingredients which might not be available in the market.

\section{Conclusion}

In summary, this study contributes to the exploration of Shariah-compliant hoteliers' challenges in implementing Muslim friendly hospitality services (MFHS) in their organizations. From the findings, this study has identified a list of main challenges faced by Shariahcompliant hoteliers which can be a point of reference for current and future hotel managers (Table 3). Managers of hotels who aspire to be Shariah-compliant or Muslim-friendly can use the list as a guide for them in initiating plans towards that. It is recommended that hoteliers be aware and update themselves with current knowledge in Muslim-friendly services so that further improvements can be made to enhance their services to Muslim guests.

Table 3: Main Challenges faced by SCH

\begin{tabular}{|c|l|}
\hline NO. & \multicolumn{1}{|c|}{ CHALLENGES } \\
\hline 1. & Changing existing facilities in the hotels \\
\hline 2. & Customer's perception \\
\hline 3. & Customer and supplier's compliance \\
\hline 4. & Satisfying diverse customers \\
\hline
\end{tabular}

\section{Acknowledgement}

The research is funded by Universiti Putra Malaysia's PUTRA grant (IPS)-Project Code GPIPS/2018/9655300.

\section{References}

AlBattat, A. R. S., \& Mat Som, A. P. (2013). Employee Dissatisfaction and Turnover Crises in the Malaysian Hospitality Industry. International Journal of Business and Management, 8(5), 62-71. https://doi.org/10.5539/ijbm.v8n5p62

CrescentRating. (2017). CrescentRating. Retrieved May 24, 2017, from https://www.crescentrating.com/

COMCEC Coordination Office. (2017). Muslim Friendly Tourism: Regulating Accommodation Establishments In the OIC Member Countries. In COMCEC Coordination Office. Retrieved from http://www.mod.gov.tr/Lists/RecentPublications/Attachments/128/Muslim Friendly Tourism (MFT) Regulating Accommodation Establishments in the OIC Member Countries.pdf

Department of Standards Malaysia. (2015). MS 2610:2015- Muslim Friendly Hospitality Services- Requirements. Department of Standards Malaysia.

Henderson, J. C. (2010). Sharia-Compliant Hotels. Tourism and Hospitality Research, 10(3), 246-254. https://doi.org/10.1057/thr.2010.3

Islamic Tourism Centre. (2017). Islamic Tourism Centre of Malaysia. Retrieved August 5, 2017, from http://www.itc.gov.my/

Jais, A. S. (2017). Shariah Compliance Hotels \& Accommodations (First Edit). Malacca: 
Politeknik Merlimau Melaka.

Karim, M. H. A., Ahmad, R., \& Zainol, N. A. (2017). Differences in Hotel Attributes: Islamic Hotel and Sharia Compliant Hotel in Malaysia. Journal of Global Business and Social Entrepreneurship (GBSE), 1(2), 157-169.

Mohd, F. M. Y. (2011). Hotel Patuh Shariah (Shariah Compliant Hotels) Sebagai Produk Baru Industri Pelancongan di Malaysia. Persidangan Kebangsaan Ekonomi Malaysia Ke VI (PERKEM VI), 2, 477-480. Malacca.

Mustaffa, R. (2016, May 23). Syariah-Compliant Hotels making a Promising Headstart. Malaysiakini. Retrieved from https://m.malaysiakini.com/news/342629

Rosenberg, P., \& Choufany, H. M. (2009). Spiritual Lodging - the Sharia - Compliant Hotel Concept. HVS Global Hospitality Services- Dubai, (April), 1-7. https://doi.org/10.1016/j.dss.2003.08.004

Samori, Z., \& Rahman, F. A. (2013). Establishing Shariah Compliant Hotels in Malaysia: Identifying Opportunities, Exploring Challenges. West East Journal of Social Sciences, 2(2), 95-108.

Samori, Z., \& Sabtu, N. (2014). Developing Halal Standard for Malaysian Hotel Industry: An Exploratory Study. In Procedia - Social and Behavioral Sciences (Vol. 121, pp. 144-157). Elsevier B.V. https://doi.org/10.1016/j.sbspro.2014.01.1116

Satar, N. F. M. (2016, July 15). Industri Pelancongan Patuh Syariah Beri Keuntungan. Berita Harian. Retrieved from https://www.bharian.com.my/node/173894 